\title{
Vocabulary Learning Strategies and Arabic Vocabulary Size among Pre-University Students in Malaysia
}

\author{
Harun Baharudin ${ }^{1} \&$ Zawawi Ismail ${ }^{2}$ \\ ${ }^{1}$ Faculty of Education, Universiti Kebangsaan Malaysia, Malaysia \\ ${ }^{2}$ Faculty of Education, Universiti Malaya, Malaysia \\ Correspondence: Harun Baharudin, Faculty of Education, Universiti Kebangsaan Malaysia, 43600 UKM Bangi, \\ Selangor, Malaysia. Tel: 601-2378-2207. E-mail: harunbaharudin@ukm.edu.my
}

Received: July 22, 2014 Accepted: November 5, 2014 Online Published: December 21, 2014

doi:10.5539/ies.v7n13p219 URL: http://dx.doi.org/10.5539/ies.v7n13p219

\begin{abstract}
Vocabulary learning strategies and vocabulary size are among the main factors that help determine how students learn second language vocabulary. The present study was an attempt to exploring the relationship between vocabulary learning strategies and Arabic vocabulary size of 742 pre-university in Religious High School (SMKA) and Government-Aided Religious School (SABK). TAV test and Schmitt's (1997) vocabulary learning strategies questionnaire including 5 categories (Determination, Social, Memory, Cognitive and Metacognitive) were used in present study. The major findings of this study were as follows: First, descriptive statistical analyses showed that the most frequent learning strategies was indicated that the most preferred vocabulary learning strategy category of all was related to determination strategies. Social strategies ranked the second. Memory, cognitive and the metacognitive strategies ranked the third to the fifth. Next, pre-university students reported not having the average vocabulary size to accommodate advanced studies at university level. Finally, the findings of the study revealed there was a relationship between the use of vocabulary learning strategies and Arabic vocabulary size.
\end{abstract}

Keywords: language learning strategies, vocabulary-learning strategies, vocabulary size

\section{Introduction}

The lexical factor in language learning is crucial and is also one of the main conditions in mastering a language (Hunt \& Belglar, 2005; Murcia, 2007; Erten \& William 2008; Amber, 2010). The mastery of vocabulary has to be facilitated via implicit or explicit approaches (Ellis, 1994; Coady, 1997; Schmitt, 2000; Sharinllah \& Hajar, 2004). Both approaches are found to be complementary in vocabulary learning (Schmitt 2000) and have to be emphasized upon in the efforts to assist students in vocabulary learning. However, explicit efforts have been found to receive less emphasis in the teaching and learning of Arabic vocabulary (Ryding, 2006; Al-Batal, 2006; Che-Radiah \& Norhayuza, 2011), especially studies which involve vocabulary learning strategies and vocabulary size.

The explicit approach is very beneficial in the early stages of vocabulary learning (Nielsen, 2002; Sharinllah \& Hajar, 2004). It is an approach, which facilitates the efforts to increase vocabulary size (Wong \& Abdullah, 2003). The explicit approach is more beneficial especially when the students are at the early stages of language learning, where their language mastery is still weak (Folse, 2004; Coady, 1997). Continuous neglect towards the explicit approach causes students to experience difficulty in increasing their vocabulary as well as difficulty in implementing the implicit approach at a later stage.

Research in vocabulary learning strategies (VLS) explores the involvement of students in the process of vocabulary learning. Originally, VLS was known as one of the sub-strategies of language learning (SLL). However, a few researchers were of the opinion that the importance of VLS seemed to be more outstanding compared to SLL in second language learning (Kojic-Sabo \& Lightbown, 1999; Schmitt, 1997; Tomoko \& Osamu (2009). The VLS research orientation focuses on the effectiveness of individual strategy in vocabulary learning which assists students in selecting, monitoring and self-evaluation. This enables students to apply cognitive strategies in order to strengthen the relationship between strategy use and vocabulary learning achievement (Gu, 2005; Macaro, 2005). 
Many researchers frequently emphasize on the four main language skills in Arabic language learning which are speaking, reading, listening and writing. Consequently, the importance of vocabulary in language learning has been sidelined. This oversight has caused the majority of the teaching and learning process of vocabulary in classrooms to occur implicitly as an additional activity; for instance, vocabulary learning through reading activities (Fan, 2003; Catalan, 2003, Al-Shuwairekh, 2001). Even worse, many of vocabulary learning activities take place in an ad hoc manner without proper planning (Catalan, 2003). Ideally, the aspect of Arabic vocabulary in Malaysia should be emphasised upon in order for the teaching and learning activities to become more well structured (Taib, 2005). The implicit approach, coupled with ad hoc teaching and learning activities for vocabulary and the neglect of explicit approaches contributed to the lack in students' vocabulary knowledge and vocabulary size.

\section{Classification of Vocabulary Learning Strategies}

Vocabulary learning strategies are ways used by students when learning new vocabulary. VLS constitute knowledge about what students do to find out the meaning of new words, retain them in long-term memory, recall them when needed in comprehension, and use them in language production (Ruutmets, 2005). There are various classifications of VLS suggested by researchers such as Cohen (1990), Nation (2001), Schmitt (1997), Brown and Payne (1994). Schmitt's taxonomy is one of the most widely used classifications among researchers. It is one of the most important contributions in terms of preparing the general vocabulary learning strategy classification framework. It has comprehensive features in most aspects of vocabulary learning. This taxonomy is based on the concept of Oxford's (1990) concept of discovery, consolidation and classification system in language learning strategies.

In general, Schmitt classifies vocabulary learning strategies into two main groups, which are, (a) discovery strategies and (b) consolidation strategies. The discovery strategy involves learning in the early stages especially the initial discovery of a word's meaning whereas consolidation strategies involve the activity of learning and recalling the meaning of the words that students encounter again.

These two main strategies are similar to Nation's (1990) strategy in 'increasing vocabulary' and strategy in 'consolidating vocabulary'. Increasing vocabulary is a strategy whereby students learn to recognise new words and later begin their learning whereas consolidation of vocabulary involves building up vocabulary and reinforcing prior vocabulary knowledge.

In Schmitt's Taxonomy, the two groups of strategies can further be divided into determination strategies, social strategies, memory strategies, cognitive strategies and metacognitive strategies. Determination and social strategies are categorised under discovery strategies whereas social, memory, cognitive and metacognitive strategies are placed under consolidation strategies.

Based on this explanation, this study uses Schmitt's Taxonomy as the basis of this study. It has been developed based on Oxford's (2003) classification of language learning strategies (LLS). Pre-university students learning the Arabic language are used as the sample of this study. The use of VLS classification is further influenced by a few factors such as proficiency, motivation and culture (Schmitt, 2000). This is because culture and environment can influence students' choice of learning strategies (Schmitt, 2000).

\section{Size of Arabic Vocabulary}

Vocabulary size refers to the aspect of quantity and it is defined as the number of words known by an individual at a certain level of language proficiency (Nation, 2001). A student who possesses a large vocabulary size also possesses the biggest part of any language in terms of meaning (McCarthy, 1988).

The mastery of vocabulary size is also one of the yardsticks for measuring a person's language proficiency. By mastering a large number of words, it is easier for a student to learn something new and learn a language (Curtis, 2006). Besides that, vocabulary size is also related to the ability to acquire reading skills, writing skills, speaking skills as well as having the ability to influence academic achievement (Saville-Troike, 1984; Laufer, 1997; Chang, 2005; Chang \& Read, 2006).

Nation has divided vocabulary based on the frequency and communicative dimension, which differentiates between high frequency vocabulary, academic vocabulary, technical vocabulary and low frequency vocabulary. For high frequency words, which need to be learnt by students, the vocabulary size needed is estimated to be around 3,000-5,000 words. According to Laufer (1998), high school students require a vocabulary size around 3,500-4,000 words. In one of his studies, Laufer stated that a student requires a minimum of 3,000 words and a maximum of 5,000 words in order to acquire reading skills more easily. Based on these views, the vocabulary size needed in order to master the English language is estimated to be around 3000 to 5000 words. 
The same applies to the vocabulary size for Arabic language. A number of experts suggested that students at an elementary level need to master as much as 750 to 1000 words, intermediate level students need to master as much as 1000 to 1500 words whereas advanced level students need to master as much as 1500 to 2000 words (Tu'aymah, 1986). Taib (2006), on the other hand, divided the required vocabulary size into three stages, which is 1000 to 1500 words at the first stage, 1500 to 2500 words at the second stage and 2500 to 3500 words at the third stage. Furthermore, Al-Batal (2006) estimated that the number of vocabulary needed to achieve a high proficiency is between 3000 to 3500 words. A vocabulary size like this is sufficient considering that students also need to utilise dictionaries and morphology knowledge in the learning of Arabic vocabulary (Tu'aymah, 1986; Al-Batal, 2006).

In the context of the Arabic language education in Malaysia, mastery of vocabulary size based on the objectives specified in the syllabus. Vocabulary size is available in the list of words provided by the Arabic language textbooks through the Curriculum Division, Education Division Islam (BPI) for each level. Starting from the jQAF program, the objectives of the Arabic language should target students need to master at least 600 words Arabic vocabulary of at least 600 words (Arabic syllabus jQAF). Arabic vocabulary at this stage revealed in stages based on thematic or situations in which students need to master the vocabulary as much as 120 words per year.

For high school students, require a vocabulary size around 3,000 words of Arabic vocabulary lists are available on the textbook according to the objectives of the Arabic Language for Communication (BAK), (Ministry of Education, 2002a). While the subject of Advance Arabic Language (BAT), the students need to master the Arabic vocabulary, around 2,000 words from the vocabulary lists are available on the textbook (BAT syllabus, Ministry of Education (2002b). Yet according to the Arabic Language syllabus (2006), students are encouraged to be able to master the Arabic vocabulary size not less than 1500 words and skilled use of the right of use (Arabic Language in KBSM syllabus, 2006). Based on these views, the vocabulary size needed in order to master the Arabic language is estimated to be around 3000 words.

Table 1. Vocabulary size according to the syllabus of the ministry of education, Malaysia

\begin{tabular}{ll}
\hline Level & Vocabulary Size \\
\hline Arabic Language for Communication (BAK) & 3000 \\
Advance Arabic Language (BAT) & 2000 \\
Arabic Language in KBSM syllabus & 1500 \\
Arabic language in jQAF (Jawi, Quran, Arabic \& Fardhu Ain) program & 600 \\
\hline
\end{tabular}

\section{Research Objectives}

The main purpose of this study is to identify the use of vocabulary learning strategies (VLS) and Arabic vocabulary size among pre-university students in religious high school (SMKA) and government-aided religious school (SABK). The objectives of this study is to: a) identify the level of use of VLS among religious secondary school students, b) identify the estimated vocabulary size of Arabic language students, and c) identify the relationship between the level of use of VLS and the vocabulary size of the Arabic language students.

Based on the study objectives, the research questions are as follow:

What is the level of students' VLS use?

What is the level of students' Arabic vocabulary?

Is there a significant relationship between the level of VLS use and students' Arabic vocabulary size?

\section{Methodology}

The design of this study is the survey that used questionnaires based on the Arabic Vocabulary Learning Strategies. The questionnaire was created and modified based on Bannet's (2006) vocabulary learning strategies questionnaires set which have been adapted from Schmitt's (1997, 2000) vocabulary learning strategies questionnaires set. The questionnaires contain 54 questions involving five key strategies, which are determination, social, memory, cognitive and meta-cognitive strategies.

These questionnaire items have been translated into Malay language (back translation) (Brislin, 1970) with modifications and added examples to enable school students to understand the statements clearly. There were a 
few additional items (vocabulary learning strategies) which were presumably used by most Arabic language students. 8 items were added to the questionnaire based on previous studies. The questionnaires have gone through the validity and reliability process first and have been pilot tested in a religious high school in Pahang, Malaysia. The questionnaire instrument obtained a .94 Cronbach alpha value and this has shown its reliability at the highest level.

For the purpose of measuring the students' vocabulary size, this study employed a Test of Arabic Vocabulary (TAV) (Harun et al., 2014). This Arabic language vocabulary test is simply a proficiency test that is not based on any particular syllabus. 40 words representing 4000 words will be tested through this test. This test was built based on discrete contract, which is to measure basic vocabulary knowledge or to use free construct. This test employed a simple test structure by only taking into account basic vocabulary knowledge and not grammatical knowledge or reading proficiency. A test procedure commonly used is to choose words based on the frequency word list.

This study involved pre-university students in 15 religious high schools (SMKA) and government-aided religious schools (SABK) all over Malaysia. These schools are divided into four zones which are north, south, east and west. A total of 742 pre university students in SMKA and SABK participated.

\section{Findings}

Based on the results of the study, the overall mean for VLS items is 2.85 and the standard deviation of 0.47 remains at moderate level. The findings of this study show that the level of usage of VLS among students in religious secondary schools is at a moderate level.

The results for this study also show that the overall score for the main category of VLS is at a moderate level. Table 2 shows a mean score analysis of main VLS strategies which are determination strategies with the highest mean score $(M=3.03, S . D=0.58)$, social strategies $(M=2.97, S . D=0.58)$, memory strategies $(M=2.80, S . D=$ $0.52)$, metacognitive strategies $(M=2.76, S . D=0.59)$ and cognitive strategies $(M=2.66, S . D=0.62)$.

Table 2. Mean and standard deviation of the usage of VLS according to the main strategies category

\begin{tabular}{llll}
\hline Main VLS Strategies & Mean & S.D & Interpretation \\
\hline Determination & 3.03 & 0.58 & Moderate \\
Social & 2.97 & 0.58 & Moderate \\
Memory & 2.80 & 0.52 & Moderate \\
Metacognitive & 2.76 & 0.59 & Moderate \\
Cognitive & 2.66 & 0.62 & Moderate \\
\hline Overall & $\mathbf{2 . 8 5}$ & $\mathbf{0 . 4 7}$ & Moderate \\
\hline
\end{tabular}

Referring to Table 3, this study showed an achievement score between 0-1000 words for 596 students (80.3\%), an achievement score between 1100-2000 words for 133 students (17.9\%) and an achievement score between 2100-3000 words for 13 students (1.8\%). Meanwhile, not a single student achieved a score between 3100-4000 words. The results demonstrate that the majority of students have a vocabulary size of not more than 1000 words. The overall mean score for the mastery level of vocabulary size is 7.17 with a standard deviation of 4.51 . The overall number of words answered correctly by students totalled 5321. This showed that the average Arabic language vocabulary size among pre-university students is 717 out of 4000 words (17.9\%).

Table 3. Vocabulary size based on vocabulary test

\begin{tabular}{lll}
\hline Vocabulary & Frequency & Percentage \\
\hline $0-1000$ & 596 & 80.3 \\
$1100-2000$ & 133 & 17.9 \\
$2100-3000$ & 13 & 1.8 \\
$3100-4000$ & 0 & 0 \\
Total & $\mathbf{7 4 2}$ & $\mathbf{1 0 0}$ \\
\hline
\end{tabular}


Mean $=7.17, S . D=4.51$.

Table 4 shows that the overall correlative coefficient between two variables is strong that is $r=0.383$. A variance of $r^{2}=0.147$ show that 14.7 percent from the overall use of VLS is due to mastery of vocabulary size. Meanwhile 85.3 percent change in the dependent variable may be caused by other factors. This explains that the mastery of vocabulary size is strongly linked to the level of use of VLS where the relationship between the two is marked by a strong positive correlation of $r=0.383$.

Table 4. Correlation between the overall use of VLS and the mastery of Arabic vocabulary

\begin{tabular}{llll}
\hline Relationship between Variables & $\boldsymbol{r}$ & $\boldsymbol{r}^{2}$ & $\boldsymbol{p}$ \\
\hline Overall use of VLS-Vocabulary size & .383 & .147 & .000 \\
\hline
\end{tabular}

\section{Discussion and Implications of Study}

This study found that pre-university students learning Arabic language from SMKA and SABK were moderate users of VLS. This level of moderate use does not exceed the mean value of 3.0 and leans towards to a level of low use. The results also show that most students did not exploit a few strategies when learning Arabic vocabulary. Only 5 strategies, which represent only $11 \%$ of VLS, were used frequently. These strategies were identified as popular strategies, which were commonly used by students when learning a second language. Strategies, which are advanced, modern, involve challenging learning activities; require increased mental activity as well as supporting materials such as social media were not fully exploited by the students. This is due to a lack of exposure towards VLS and a lack of supporting tools and materials, which led to students not fully utilizing the other strategies in order to consolidate their vocabulary learning.

The implication for VLS (and language learning strategy in general) training is that making the learners aware of the strategies they might employ is not enough. Instruction has to be explicit and students informed about the value and purpose of learning strategies as well as their potential use, as will be restated and presented in the following chapter.

The findings of this study are consistent with other studies conducted in Malaysia such as studies by Nurazan (2004) and Ahmad (2008). At the same time, the findings are similar to a few studies conducted in foreign countries such as the ones done by Zarafshan (2002), Sarani and Kafipour (2008) and Kafipour (2010) which found that second language learners are moderate users of VLS.

The mastery level of Arabic language vocabulary size among religious secondary school students remains at a low level. This low level of mastery shows that much has to be done before we finally achieve targeted syllabus objectives and recommendations by experts. Most language experts recommend that the vocabulary size for higher level students should be 3000 and above. This finding is consistent with studies done by Irma-Martiny (2012), Saifudin (2002), Osman (1990), Zaulqarnain and Zamri (1990), Ishak (1993) and Ab. Rahim (1994) which found that Arabic language vocabulary size among students is low and has not achieved the targeted learning objectives set by the syllables and experts' recommendations.

In other words, the findings show that the mastery of vocabulary size is still weak among students. This situation demonstrates how the learning of Arabic vocabulary has yet to achieve the targets set by syllables objectives for the Arabic language subject. Besides that, the low level of Arabic vocabulary size mastery further proves that the explicit learning of vocabulary is not sufficiently emphasized upon among students. The role of VLS which supports the learning of vocabulary learning explicitly enables a more effective mastery of vocabulary size (Wong \& Abdullah, 2003). This also seems to support the findings, which show that the use of VLS in this study has not been optimised fully.

Based on the third research question, the findings of this study found that there is a significant relationship and a strong overall correlativity between VLS and the mastery of Arabic vocabulary size. This correlative value means that respondents who show a high usage of VLS will also achieve a high score in Arabic vocabulary size. In short, the findings indicate that students who frequently use vocabulary learning strategies will see an improvement in their vocabulary size.

This study is also supported by several other studies such as Curtis (1987) who stated that the use of VLS directly influences the vocabulary size of students. Cusen (2005), on the other hand, explained that there is a strong correlation between the use of VLS and vocabulary size compared to other variables. Schmitt (1997) 
supports that vocabulary size can be increased rapidly when VLS is used in a correct way. This finding is consistent with a few previous studies such as the ones done by Meara and Bell (2001), Meara and Fitzpatrick (2000), Sener (2009), Alemdari (2010), Sahandri, Reza, and Kumar (2009), Tinutda and Waraporn (2011) and Seyed and Bahar (2012) which found a positive and significant correlation between the use of VLS and vocabulary size. All this shows that the use of VLS has indeed a strong influence on the mastery of Arabic vocabulary.

\section{References}

Ahmad, I. H. (2008). Perception of Vocabulary Learning Strategies among ESL Students in a Selected Secondary School in Melaka (M.A thesis, Bangi: Universiti Kebangsaan Malaysia).

Al-Batal, M. (2006). Playing with words: teaching vocabulary in the Arabic curriculum. In K. Wahba, Z. Taha, \& L. England (Eds.), Handbook for Arabic language teaching profesionals in the 21st century (pp. 331-340). Mahwah, New Jersey: Lawrence Erlbaum Associates Publishers.

Alemdari, Z. S. (2010). The relationship between vocabulary learning strategies employed by university level English language learners and their success (Unpublished M.A dissertation). Hacettepe University, Ankara.

Azhar, M., Ahmad, K., Mohamed. \& Sulaiman, S. M. N. (2003). Masalah penterjemahan Melayu-Arab di kalangan pelajar Melayu. Persidangan Penterjemahan Antarabangsa ke-9 (pp. 344-361). Kuala Lumpur: Universiti Pendidikan Sultan Idris.

Bannett, P. (2006). An Evaluation of Vocabulary Teaching in an intensive Study Programme (Unpublished MA thesis). University of Birmingham, United Kingdom.

Brislin, R. W. (1970). Back-translation for cross-cultural research. Journal of Cross-Cultural Psychology, 1, 185-216. http://dx.doi.org/10.1177/135910457000100301

Brown, C., \& Payne, M. E. (1994). Five essential steps of processes in vocabulary learning. Paper presented at the TESOL Convention. Baltimore: Md.

Catalan, R. (2003). Sex differences in L2 vocabulary strategies. Journal of Applied Linguistics, 13(1), 54-77. http://dx.doi.org/10.1111/1473-4192.00037

Chang, C.-S. (2005). The effect of lexical support in EFL listening comprehension tests. The proceedings of the $22^{\text {nd }}$ International Conference on English Teaching and Learning in the Republic of China. Crane, Taipei, Taiwan, pp. 13-27.

Chang, C.-S., \& Read, J. (2006). The effect of listening support on the listening performance of EFL learners. TESOL Quarterly, 40, 375-397. http://dx.doi.org/10.2307/40264527

Che' Pee, C. H. (1991). Pelajar sekolah menengah agama: Cabaran dan masa hadapan. Jurnal Pendidikan Islam, 3, 13-16.

Che-Radiah, M., \& Norhayuza, M. (2011). Pengajaran dan pembelajaran kosa kata Arab; Teori \& aplikasi. Serdang: Penerbit UPM.

Cohen, A. D. (1990). Language Learning: Insight for Learners, Teachers and Researchers. New York: Newbury House/Harper Row.

Cunningsworth, A. (1995). Choosing your coursebook. Oxford: Heineman.

Cusen, G. (2005). Investigating vocabulary learning strategies: A case study of Romanian undergraduates with a professional interest in learning English $s$ a foreign language (Ph.d's Thesis, Lancaster University, Lancaster, United Kingdom).

Fan, Y. M. (2003). Frequency of use, perceived usefulness and actual usefulness of second language vocabulary strategies: A study of Hong Kong learners. The Modern Language Journal, 87(2), 222-241. http://dx.doi.org/10.1111/1540-4781.00187

Folse, K. (2004). Vocabulary myths: applying second language research to classroom teaching. Ann Arbor: MI: University of Michigan Press.

Gu, P. (2005). Learning strategies: Prototypical core and dimensions of variation. Retrieved from http://www.crie.org.nz/research_paper/Peter_GU.pdf

Harun, B., Zawawi, I., Adelina, A., \& Normala, B. (2014). TAV of Arabic Language Measurement. Mediterranean Journal of Social Sciences, 5(17), 2401-2409. 
Hunt, A., \& Belglar, D. (2005). A framework for developing EFL reading vocabulary. Reading in a Foreign Language, 17, 1-31.

Irma-Martiny, M. Y. (2012). Hubungan strategi pembelajaran kosa kata dengan tahap penguasaan kosa kata pelajar (M.A dissertation, Universiti Kebangsaan Malaysia, Bangi).

Kafipour, R. (2010). Vocabulary learning strategies, vocabulary knowledge and reading comprehension of EFL undergraduate students in Iran (PhD thesis, UPM, Serdang).

Kojic-Sabo, I., \& Lightbown, P. (1999). Students' approaches to vocabulary learning and their relationship to success. Modern Language Journal, 83, 176-192. http://dx.doi.org/10.1111/0026-7902.00014

Landau, J. M. (1959). A Word Count of Modern Arabic Prose. New York: American Council of Learned Societies.

Laufer, B. (1998). The development of passive and active vocabulary in a school language: Same or different? Applied Linguistics, 19, 225-271. http://dx.doi.org/10.1093/applin/19.2.255

Macaro, E. (2005). Fourteen features of a language leaner strategy. Retrieved from http://www.crie.org.nz/research_paper?Ernesto_Macaro_WP\$.pdf

McCarthy. (1988). Vocabulary and Language Teaching. New York: Longman.

Ministry of Education. (2002a). Sukatan Pelajaran Bahasa Arab Komunikasi. Kuala Lumpur: Jabatan Pendidikan Islam dan Moral.

Ministry of Education. (2002b). Sukatan Pelajaran Bahasa Arab Tinggi KBSM. Kuala Lumpur: Jabatan Pendidikan Islam dan Moral.

Murcia, U. (2007). Research on second vocabulary acquisition and learning. IJES, 2(7), vii-xvi.

Nation, P. (1990). Teaching and learning vocabulary. Boston, Mass: Heinle \& Heinle Publishers.

Nation, P. (2001). Learning Vocabulary in Another Language. Cambridge: Cambridge University Press. http://dx.doi.org/10.1017/CBO9781139524759

Nation, P., \& Waring, R. (1997). Vocabulary size, text coverage and word lists. In N. Shcmitt, \& M. McCarthy (Eds.), Vocabulary Description, Acquisition and Pedagogy (pp. 6-19). Cambridge: Cambridge University Press.

Nielsen, B. (2002). A Review of Research into Vocabulary Learning and Acquisition. Retrieved from http://www.kushiroct. ac.jp/library/kiyo/kiyo36/Brian.pdf

Nurazan, M. R. (2004). Strategi pembelajaran bahasa dalam pembelajaran bahasa Arab: Kajian di KUSZA. Disertasi Sarjana: Universiti Kebangsaan Malaysia.

Nurul, H. U. (2009). Muqarrar ta'lim al-lughat al-'arabiah li natiqin ni ghayriha madkhal taqwimi. Gombak: IIUM Press.

Oxford, R. (1990). Language learning strategies: What every teacher should know. Boston: Newbury House.

Rahim, R. (2009). Penguasaan Perbendaharaan Kata bahasa Arab dalam kalangan murid sekolah Kebangsaan Menerusi Program J-QAF: Satu Kajian Kes. Wacana Pendidikan Islam (peringkat Nusantara) siri ke-7 (pp. 579-588). Bangi: Universiti kebangsaan Malaysia.

Ruutmets, K. (2005). Vocabulary Learning Strategies in Studying English as a Foreign Language (Master's thesis). Retrieved from http://www.utlib.ee/ekollekt/diss/mag/2005/b17557100/ruutmets.pdf

Ryding, K. (2006). Teaching Arabic in the United State. In K. Wahba, Z. Taha, \& L. England (Eds.), Handbook for Arabic Language teaching professionals in the 21th century (pp. 13-20). Mahwah, New Jersey: Lawrence Erlbaum Associates.

Saifuddin, H. (2002). Penguasaan perbendaharaan kata bahasa Arab di kalangan pelajar tingkatan tiga: Satu kajian kes di sekolah Menengah Kebangsaan (Agama) Negeri Melaka (M.A Dissertation, Universiti Malaya, Kuala Lumpur).

Sarani, A., \& Kafipour, R. (2008). The relationship between extraversion/introversion tendencies of Iranian BA student's of English and their English oral reproduction. Muenchen: Lincom GmbH.

Saville-Troike, M. (1984). What really matter in second language learning for academic achievement? TESOL Quarterly, 18, 199-219. http://dx.doi.org/10.2307/3586690 
Schmitt, N. (1997). Vocabulary learning strategies. In N. Schmitt, \& M. McCarthy (Eds.), Vocabulary: Description, Acquisition and Pedagogy (pp. 199-227). Cambridge: Cambridge University Press.

Schmitt, N. (2000). Vocabulary in Language Teaching. Cambridge: Cambridge University Press.

Seyed, A. R. K., \& Bahar, P. (2012). Vocabulary learning strategies and vocabulary size of ELT students at EMU in Northern Cyprus. Canadian Centre of Science and Education, 5(4), 138-149.

Sohair, A. M. (1990). Satu tinjauan tentang masalah-masalah pengajaran mata pelajaran bahasa Arab di sekolah-sekolah menengah agama di Malaysia (M.A dissertation, Universiti Kebangsaan Malaysia, Bangi).

Tinutda, K., \& Waraporn, S. (2011). Vocabulary Learning Strategies Employed by Undergraduate Students and its Relationship to Their vocabulary Knowledge. The 3rd Intenational Coference on Humanities and Social Sciences. Songkla University: Faculty of Liberal Arts, Prince of Songkla University.

Tomoko, Y., \& Osamu, T. (2009). Language learning strategies used by lower secondary school learners in a Japanese EFL context. International Journal of Applied Linguistics, 9(2), 136-172. http://dx.doi.org/10.1111/j.1473-4192.2009.00221.x

Tu'aymah, R. A. (1986). al-marja' fi ta'lÊm al-lughah li nÉÏiq Ên bi lughah ukhrÉ. Mekah: Jami’ah Ummu al-Qurra.

Zarafshan, M. (2002). Effects of attitude and motivation on the use of language learning strategies of Iranian EFL university students (Unpublished master thesis, Shiraz Azad University, Iran).

\section{Copyrights}

Copyright for this article is retained by the author(s), with first publication rights granted to the journal.

This is an open-access article distributed under the terms and conditions of the Creative Commons Attribution license (http://creativecommons.org/licenses/by/3.0/). 